\title{
Morphological and Anatomical Observations on Seeds of Some Iris L. Taxa from Turkey
}

\author{
Mehmet Cengiz KARAİSMAİLOĞLU ${ }^{1 *}$
}

\begin{abstract}
This study includes on the taxonomic evaluation of morphological and anatomical features of seeds belonging to Iris taxa, which are I. suaveolens, I. sintenisii, I. foetidissima and I. germanica scattered in Turkey. Morphological features like dimension, shape, colour, and surface ornamentation types of seeds have studied by light and scanning electron microscopes. The structure and thicknesses of testa and parenchyma layers in seeds have examined anatomically. The obtained results show that the color, shape, testa structure and thickness of the seeds of the examined taxa are different in some respects. Furthermore, the surface ornamentations are somewhat diverse for the studied taxa at the interspecific level. As a result, it has been determined that the examined morphological and anatomical characteristics of the seeds show variations with some exceptions, and this situation has a taxonomic importance.
\end{abstract}

Keywords: Anatomy, Morphology, SEM, Seed, Turkey

\section{Türkiye'den Bazı Iris L. Taksonlarının Tohumları Üzerinde Morfolojik ve Anatomik Gözlemler}

ÖZET: Bu çalışma Türkiye'de dağılım gösteren bazı Iris taksonlarına ait (I. suaveolens, I. sintenisii, I. foetidissima ve $I$. germanica) tohumların morfolojik ve anatomik özelliklerinin taksonomik değerlendirmesini içerir. Tohumların boyutu, şekli, rengi ve yüzey ornamentasyonları ışık ve taramalı elektron mikroskobu ile çalışılmıştır. Testa ve parankima tabakalarının yapı ve kalınlığı anatomik olarak incelenmiştir. Elde edilen bulgular, incelenen taksonlara ait tohumların renk, şekil, testa yapısı ve kalınlığına ait özelliklerin bazı açılardan farklı olduğunu göstermektedir. Ayrıca, yüzey ornamentasyonları türler arası seviyede incelenilen taksonlar için kısmen farklıdır. Sonuç olarak, incelenen tohum morfolojik ve anatomik karakterlerinin bazı istisnalar ile varyasyonlar gösterdiği ve bu durumun taksonomik öneme sahip olduğu tespit edilmiştir.

Anahtar kelimeler: Anatomi, Morfoloji, SEM, Tohum, Türkiye

\footnotetext{
${ }^{\mathrm{T}}$ Mehmet Cengiz KARAİSMAİLOĞLU (Orcid ID: 0000-0002-6856-2742), , Siirt University, Faculty of Arts and Sciences, Department of Biology, Siirt, Turkey

*Sorumlu yazar/Corresponding Author: Mehmet Cengiz Karaismailoğlu, e-mail: cengiz.karaismailoglu@ siirt.edu.tr 


\section{INTRODUCTION}

Iris L. (Iridaceae), which has extensively dispersed through the Northern Temperate Area, includes over 300 taxa of flowering plants with attractive flowers mentioning to the extensive diversity of flower colors found in the various species (Jaenicke and Marner, 1990; Baser et al., 2011). Taxonomical researches on Iris genus in Turkey has been performed by Mathew (1989). According to this researcher, genus included circa 44 taxa in four subgenera as Limniris Spach, Iris L, Hermadactyloides Spach and Scorpiris Spach, respectively (Dönmez and Pinar, 2001).

Seeds and fruits present characteristic features in terms of shape, colour, dimension, seed surface micro structures, which can offer valuable contributions in classification of taxa. These features are not affected by habitat conditions and display a great variety from species to family categories (Barthlott, 1981). In addition, anatomical structures are generally as beneficial as other characters in plant classification, and they are valuable in separation of the closely related taxa (Karamian et al., 2012; Karaismailoğlu, 2015).

Morphological works of the Iridaceae taxa have been performed by many researchers (Artyushenko, 1990; Rudall, 1991; Pınar and Dönmez, 2000; Kandemir, 2009; Mitic et al., 2013; Guo, 2015; Karaismailoğlu, 2015; Zhygalova et al., 2015). However, the studied data relating to the anatomical and micromorphological structures of the seed of Turkish Iris taxa are not available. Accordingly, the aim of this work is to examine morphological and anatomical characters of seeds of Iris taxa, which are I. suaveolens, I. sintenisii, I. foetidissima and I. germanica with light and scanning electron microscopes in order to realize variances. Detailed descriptions of seed of the studied taxa have presented in this study for the first time.

\section{MATERIAL AND METHODS}

Seeds of the studied 4 species, which were collected from natural inhabitants in Turkey and cultivated at the Alfred Heilbronn Botanical Garden, were used in morphological and anatomical studies (I. suaveolens: Amasya, Boraboy, stony areas, $950 \mathrm{~m}$, 17.04.2018, Karaismailoğlu 381; I. sintenisii: Kütahya, Gediz, Murat mountain, stony areas, $1302 \mathrm{~m}$, 26.05.2014, Karaismailoğlu 37; I. foetidissima: Bolu, Abant, inclined slopes, $1700 \mathrm{~m}$, 10.04.2018, Karaismailoğlu 380, I. germanica: cultivated material). Researches were done with 10 ripe seeds for each taxon.

Macromorphological characters like the shape, size, and color of seeds were observed with utilizing a stereomicroscope (Olympus ZS51) and Kameram Imaging Software (Karaismailoğlu, 2015). In micromorphological observations, samples were prepared for scanning electron microscopy by gluing with silver paste on stubb, covered with goldplatinum, and analyzed (Karaismailoğlu, 2015).

The cross sections were obtained by a microtome (Thermo Shonda Met Finesse) from the middle of the seeds for anatomical structures such as testa thickness and shape of epidermal cells. Later, they were stained with haematoxylin (Harris-RRSP67-E) and enclosed with entellan to examine anatomical features. Anatomical characters were observed with a light microscope (Olympus CX21FS1) and Kameram Imaging Software (Karaismailoğlu, 2015).

The terminologies of morphological and anatomical characteristics were performed by Stearn (1985).

\section{RESULTS AND DISCUSSION}

In macromorphological, seed dimension, colour and shape characteristics of taxa were assessed, and variances among examined species were detected (Table 1). In seed sizes, I. suaveolens and I. germanica had the most 
significant variances among the studied species. Their values varied between $6.58 \mathrm{~mm}$ and 8.24 $\mathrm{mm}$ for length, and between 4.32 and to 6.13 $\mathrm{mm}$ for width, respectively. Colours of seeds were yellow, brown and tones. Colours of seeds were defined to be significant in separation of the studied Iris taxa. The seed shapes of the

studied taxa displayed high variations. Also, the ratio values of seed dimensions had variances, which ranged from 1.20 to 1.52 . Seeds were ellipticus in I. suaveolens (1.52), ellipticus-late in I. sintenisii (1.20), I. foetidissima (1.26), and ovatus in I. germanica (1.34) (Table 1 and Figure 1).

A
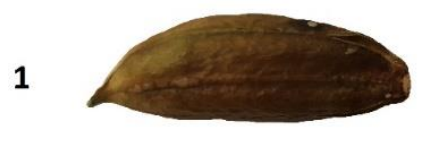

2

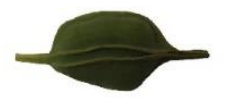

3
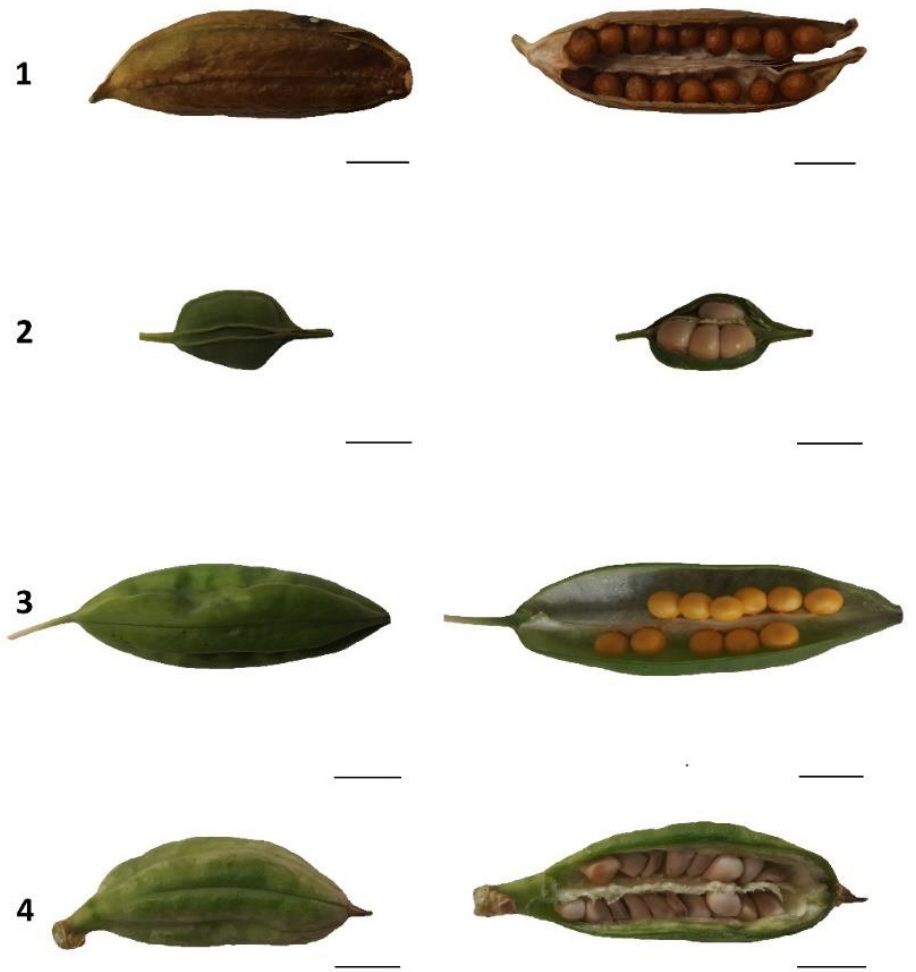

C
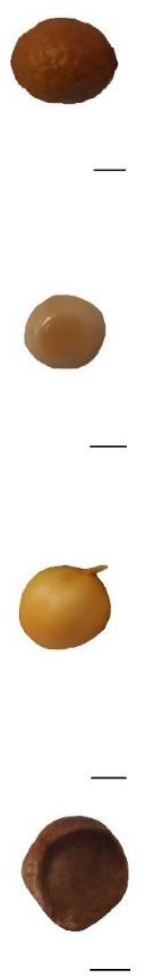

Figure 1. The examined taxa: 1: I. suaveolens, 2: I. sintenisii, 3: I. foetidissima, 4: I. germanica (A: Fruit, B: Seeds in loculus, C: Seeds, Scale Bars in A and B: $2 \mathrm{~cm}$, Scale Bars in C: $1 \mathrm{~cm}$ ).

The morphological and anatomical characters of seeds are of the main variations among taxa in various taxonomic groups. These variations present an ease in distribution of taxa at various taxonomic levels, in association of taxonomic features. Although seed characters such as micromorphological and anatomical features are available for taxonomic use (Grilli Caiola et al., 2010; Karaismailoğlu, 2015), a study including seed morphology and anatomy of Iris taxa from Turkey has not been performed until now.

In this study, macromorphological characteristics like color, shape, and size of seeds of the examined Iris taxa from Turkey were shown variations. These variations in macromorphological characters were suitable with the diagnostic features in Flora of Turkey (Davis, 1984) for the Iris species.

Seed surface ornamentations of the examined taxa showed diversity (Fig. 2 and Tab. 1). They were areolate (I. suaveolens), reticulate (I. foetidissima), reticulate-areolate (I. sintenisii) and ruminate (I. germanica) (Tab. 1). Moreover, cell shapes on the seed surfaces were variable, and they were composed of oval cells ( $I$. suaveolens and I. sintenisii), polygonal cells ( $I$. sintenisii and I. foetidissima) or undefined cells (I. germanica). 
Table 1. Morphological and anatomical characters in seeds of the examined Iris taxa. Outcomes represent mean values \pm standard deviation; means with different letters are significant at $p=0.05$ level (Duncan's multiple-range test); L: length, W: width, oe: outer epidermis, ie: inner epidermis.

\begin{tabular}{|c|c|c|c|c|c|c|c|}
\hline \multirow[b]{2}{*}{ Taxa } & \multirow[t]{2}{*}{ Colour } & \multirow[t]{2}{*}{ Shape } & \multicolumn{2}{|c|}{ Seed Dimensions } & Ratio & \multicolumn{2}{|l|}{ Seed Surface } \\
\hline & & & $\mathbf{L}(\mathbf{m m})$ & W (mm) & $(\mathrm{L} / \mathrm{W})$ & Ornamentation & $\begin{array}{l}\text { Epidermal } \\
\text { Structure } \\
\end{array}$ \\
\hline $\begin{array}{l}\text { I. suaveolens Boiss. } \\
\text { \& Reut. }\end{array}$ & Brown & Ellipticus & $6.58 \pm 0.18^{\mathrm{d}}$ & $4.32 \pm 0.21^{\mathrm{c}}$ & 1.52 & Areolate & Oval cells \\
\hline I.sintenisii Janka & $\begin{array}{l}\text { Clear } \\
\text { Brown }\end{array}$ & $\begin{array}{l}\text { Ellipticus- } \\
\text { Late }\end{array}$ & $7.15 \pm 0.25^{\mathrm{c}}$ & $5.95 \pm 0.35^{\mathrm{ab}}$ & 1.20 & Reticulate-Areolate & $\begin{array}{c}\text { Polygonal or } \\
\text { Oval cells }\end{array}$ \\
\hline I. foetidissima $\mathrm{L}$. & Yellow & $\begin{array}{l}\text { Ellipticus- } \\
\text { Late }\end{array}$ & $7.63 \pm 0.13^{b}$ & $6.04 \pm 0.21^{\mathrm{a}}$ & 1.26 & Reticulate & Polygonal cells \\
\hline I. germanica L. & $\begin{array}{l}\text { Dark } \\
\text { Brown }\end{array}$ & Ovatus & $8.24 \pm 0.27^{\mathrm{a}}$ & $6.13 \pm 0.30^{\mathrm{a}}$ & 1.34 & Ruminate & Undefined \\
\hline
\end{tabular}

Table 1 continued

\begin{tabular}{|c|c|c|c|c|}
\hline \multirow[t]{2}{*}{ Taxa } & \multicolumn{2}{|l|}{ Testa } & \multicolumn{2}{|l|}{ Parenchyma Layer } \\
\hline & Structure & $\begin{array}{l}\text { Thickness } \\
(\mu \mathrm{m})\end{array}$ & Structure & Thickness \\
\hline I. suaveolens & 6-8-layer, Flat or Crushed cells & $86.29 \pm 12.25^{\mathrm{bc}}$ & 2-3-layer, Crushed cells & $29.35 \pm 5.86^{\mathrm{ab}}$ \\
\hline I.sintenisii & $\begin{array}{l}\text { oe: 7-8-layer Crushed scleranchymatic } \\
\text { cells, ie: 5-6-layer Flat cells }\end{array}$ & $94.54 \pm 10.63^{b}$ & 1-2-layer, Flat cells & $10.38 \pm 4.72^{\mathrm{c}}$ \\
\hline I. foetidissima & 1-2-layer, Flat cells & $25.89 \pm 6.14^{\mathrm{d}}$ & 1-2-layer, Flat cells & $30.29 \pm 4.81^{\mathrm{ab}}$ \\
\hline I. germanica & $\begin{array}{l}\text { oe: 1-layer Cubic cells, ie: 6-9-layer } \\
\text { Polygonal cells }\end{array}$ & $201.19 \pm 5.16^{\mathrm{a}}$ & $\begin{array}{l}\text { 2-3-layer, Polygonal or Flat } \\
\text { cells }\end{array}$ & $35.83 \pm 2.96^{\mathrm{a}}$ \\
\hline
\end{tabular}
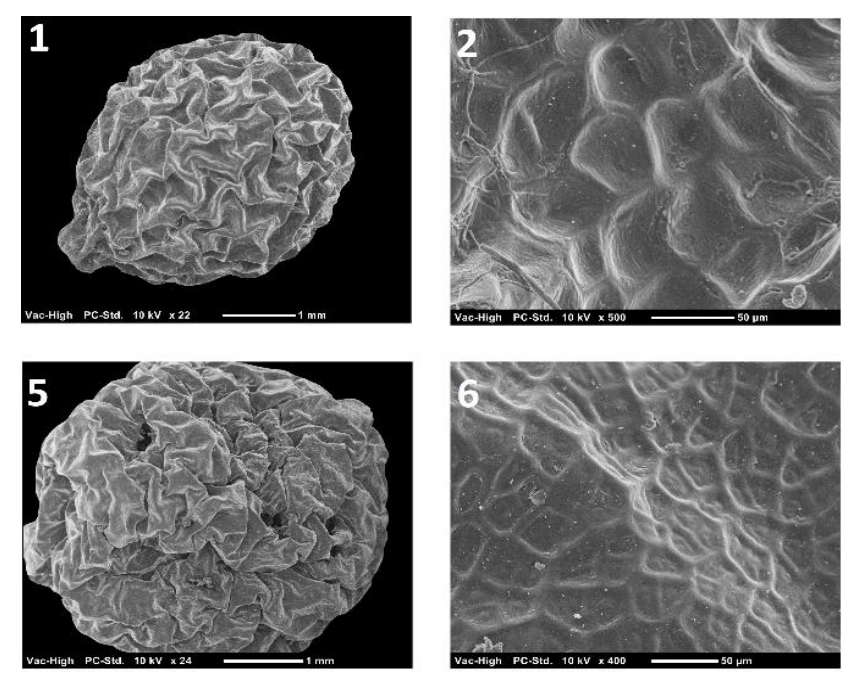
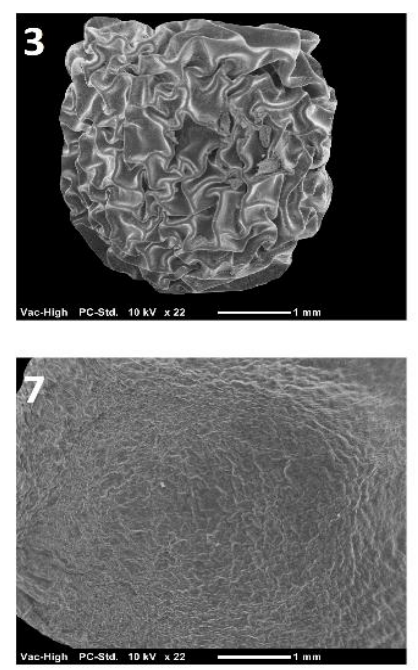

Figure 2. The micromorphological structures of the examined taxa: 1-2: I. suaveolens, 3-4: $I$. sintenisii, 5-6: I. foetidissima, 7-8: I. germanica.

Seed surface features have been commonly utilized in the explanation of taxonomic problems, in the clarification of evolutionary relations, and in the association of the adaptive structures of the seed surface (Heywood, 1971; Sulaiman, 1995; Karaismailoğlu, 2015). The surface ornamentations in the examined taxa have shown variations as areolate, reticulateareolate, reticulate and ruminate. The surface ornamentations of seeds are useful characters in classification of the examined Iris taxa. 
The seed surface types assist in the utilized characteristics in systematics of the genus (Davis, 1984). These results are also compatible with studies conducted with various genera such as Crocus (Grilli Caiola et al., 2010; Harpke et al., 2014; Carta et al., 2015; Kerndorff et al., 2015 and 2016), Romulea (Karaismailoğlu, 2015), Gladiolus (Zhygalova et al., 2015) within the family.

The anatomical characters of the seeds of four Turkish Iris were presented in Table 1 and Figure 3. Accordingly, the mean values of testa thickness varied between $25.89 \mu \mathrm{m}$ and 201.19 $\mu \mathrm{m}$, and this characteristic ranged meaningfully among the studied taxa. A thick testa was recorded in I. germanica, while the testa in $I$. foetidissima is thin (Tab. 1). In other aspects,
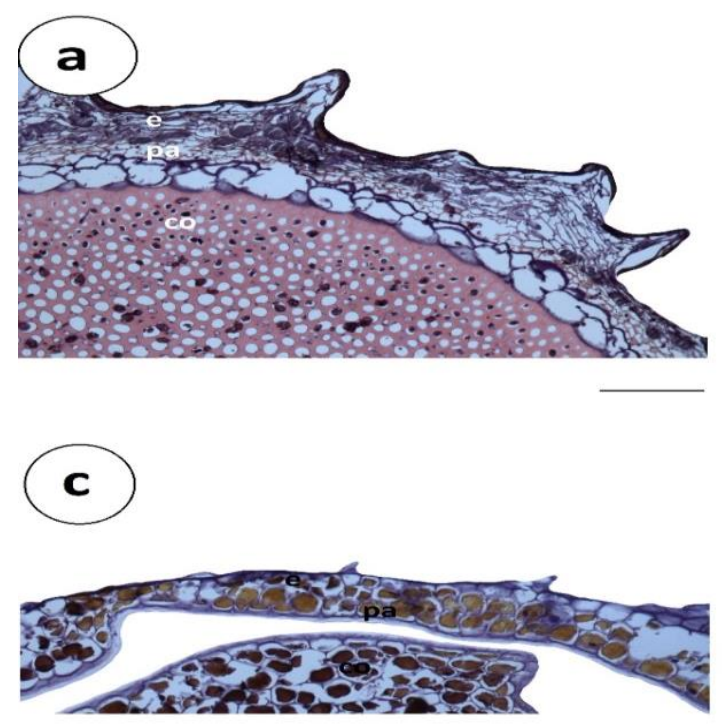

shapes and layer number of epidermal cells of testa were differed in the examined taxa (Tab. 1), which had flat, crushed, cubic and polygonal cells in unequal or equal forms, and thick or thin walls with 1-14 layer in cross sections (Figure 3). In addition to these outcomes, testa in $I$. sintenisii and I. germanica were occurred from two layers as outer and inner. The outer epidermis cells of $I$. sintenisii were scleranchymatic structure unlike other taxa examined. Parenchyma layer of the seeds was shown to range from 10.38 to $35.83 \mu \mathrm{m}$, and it was occurred from flat (I. sintenisii, I. germanica and I. foetidissima), crushed (I. suaveolens) and polygonal cells (I. germanica) in shapes (Figure $3)$.
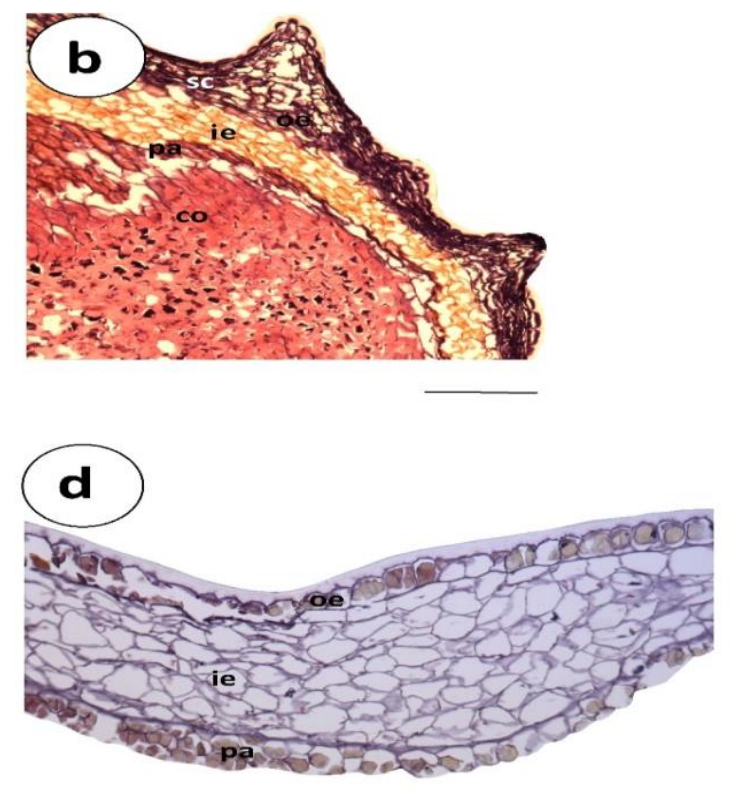

Figure 3. The anatomical structures of seeds of the examined taxa: a: $I$. suaveolens, b: $I$. sintenisii, c: $I$. foetidissima, d: I. germanica (e: epidermis, sc: scleranchyma, oe: outer epidermis, ie: inner epidermis, pa: parenchyma, co: cotyledon, Scale bars: $100 \mu \mathrm{m})$.

The anatomical structures of the testa and epidermal cells of the seeds may offer valuable information for phylogenetic classification of angiosperm taxa (Corner, 1976). In this study, the variations in the examined anatomical characters such as testa structure and thickness, parenchyma layer structure and thickness of the examined Iris taxa have been recognized. The anatomical characters used in this preliminary study may contribute to the systematic of genus. These outcomes are consistent with earlier works in Iridaceae (Grilli Caiola et al., 2010; Karaismailoğlu, 2015). 


\section{CONCLUSION}

This work supports the use of the morphological and anatomical features of the seeds as the distinctive characters in the classification within the Iris taxa in Turkey. This is a preliminary work to define the applicability of the examined characteristics, and further investigations covering all taxa of the genus are required for determining the complete differences and better understanding systematic of genus.

\section{ACKNOWLEDGEMENTS}

The author thanks the professors in Istanbul University, Division of Botany for providing the facilities of some equipments.

\section{REFERENCES}

Artyushenko ZT, 1990. The atlas on the describing morphology of the vascular plants. Nauka Publ. house, LeningradRussia.

Baser KHC, Demirci B, Orhan IE, Kartal M, Sekeroglu N, Sener B, 2011. Composition of Volatiles from Three Iris Species of Turkey. Journal of Essential Oil Research, 23 (4): 66-71.

Barthlott W, 1981. Epidermal and seed surface characters of plants: Systematic applicability and some evolutionary aspects. Nordic Journal of Botany, 1: 345355.

Carta A, Moretti M, Nardi FD, Siljak-Yakovlev S, Peruzzi L, 2015. Seed morphology and genome size in two Tuscan Crocus (Iridaceae) endemics: C. etruscus and $C$. ilvensis. Caryologia, 68 (2): 97-100.

Corner EJH, 1976. The seeds of Dicotyledons, Vol 1. Cambridge University Press, Cambridge-England.
Davis PH, 1984. Flora of Turkey and the East Aegean Islands, Vol. 8. Edinburgh University Press, Edinburgh.

Dönmez EO, Pınar NM, 2001. The Clypeate pollen grains of Turkish Iris L. (Iridaceae): Subgenus Scorpiris Sach. Turkish Journal of Botany, 25: 57-62.

Grilli Caiola M, Leonardi D, Canini A, 2010. Seed structure in Crocus sativus L., $C$. cartwrightianus Herb., C. thomasii Ten., and $C$. hadriaticus Herb. at SEM. Plant Systematics and Evolution, 285: 111-120.

Guo J, 2015. Comparative Micromorphology and Anatomy of Crested Sepals in Iris (Iridaceae). International Journal of Plant Science, 176 (7): 627-642.

Harpke D, Peruzzi L, Kerndorff H, Karamplianis $\mathrm{T}$, Constantinidis T, Ran đelović V, Ranđelović N, Juković M, Pasche E, Blattner FR, 2014. Phylogeny, geographic distribution and new taxonomic circumscription of the Crocus reticulatus species group (Iridaceae). Turkish Journal of Botany, 38: 1182-1198.

Heywood WH, 1971. Scanning electron microscopy. Academic Press, LondonEngland.

Jaenicke L, Marner FJ, 1990. The irones and their origin. Pure and Applied Chemistry, 62: $1365-1368$.

Kandemir N, 2009. A morphology, anatomy and ecology of critically endangered endemic Crocus pestalozzae Boiss. (Iridaceae) in North-West Turkey. Bangladesh Journal of Botany, 38 (2): 127-132.

Karaismailoğlu MC, 2015. Morphological and anatomical features of seeds of Turkish Romulea taxa (Iridaceae) and their taxonomic significance. Acta Botanica Croatica, 74: 31-41. 
Karamian R, Behjou AM, Ranjbar M, 2012. Anatomical findings of Onobrychis sect. Heliobrychis (Fabaceae) in Iran and their taxonomic implications. Turkish Journal of Botany, 36: 27-37.

Kerndorff H, Pasche E, Harpke D, 2015. The Genus Crocus (Liliiflorae, Iridaceae): Lifecycle, Morphology, Phenotypic Characteristics, and Taxonomical Relevant Parameters. Stapfia, 103: 27-65.

Kerndorff H, Pasche E, Harpke D, 2016. The Genus Crocus (Liliiflorae, Iridaceae): A Descriptive Seed Morphology. Part one: Macroscopic Traits and Phylogenetic Relevance. Stapfia, 105: 3-41.

Mathew B, 1989. A taxonomic revision of Iris Subgenus Hermodactyloides (Iridaceae) in plant taxonomy, Phytogeography, and related subjects. Edinburg Univ. Press, Edinburg.

Mitic B, Halbritter H, Sostaric R, Nikolic T, 2013. Pollen morphology of the genus Iris L. (Iridaceae) from Croatia and surrounding area: taxonomic and phylogenetic implications. Plant Systematics and Evolution, 299: 271-288.
Pinar NM, Dönmez EO, 2000. Pollen morphology of Turkish Iris L. (Iridaceae) with reference to evolutionary trends at the infrageneric level. Israel Journal of Plant Sciences, 48: 129-141.

Rudall P, 1991. Leaf anatomy and phylogeny of Ixioideae (Iridaceae). Botanical Journal of the Linnaean Society, 106: 329-345.

Stearn WT, 1985. Botanical Latin: history, grammar syntax, terminology and vocabulary. David \& Charles, LondonEngland.

Sulaiman IM, 1995. Scanning electron microscopic studies seed coat patterns of five endangered Himalayan species of Meconopsis (Papaveraceae). Annals of Botany, 76: 323-376.

Zhygalova S, Futorna OA, Levanets A, 2015. Micromorphological study (ultrastructure of lamina surface, seeds, ultrasculpture of pollen grains) of Gladiolus L. species (Iridaceae Juss.) of Ukrainian flora. Environmental and Socio-economic Studies, 2 (4): 21-27. 